\author{
Nemchenko V. \\ Doctor of Economics, Professor \\ Department of Accounting and Auditing \\ E-mail: bossvalera29@gmail.com \\ ORCID ID: 0000-0002-2984-3357 \\ Pchelianska G. \\ Assistant \\ Department of Accounting and Auditing \\ E-mail: gaya od@ukr.net \\ ORCID ID: 0000-0003-0944-986X
}

\author{
Markova T. \\ Ph.D., Associate Professor \\ Department of Accounting and Auditing \\ E-mail: markova.tetiana17@gmail.com \\ ORCID ID: 0000-0002-9437-2635 \\ Volodina 0. \\ Assistant \\ Department of Foreign Languages \\ Odessa National Academy of Food Technologies \\ Kanatna str., 112, Odesa, Ukraine, 65039 \\ E-mail: volodinaolenaonaft@gmail.com \\ ORCID ID: 0000-0003-0552-6733
}

\title{
INFORMATION TECHNOLOGIES IN THE USE OF INNOVATIVE TEACHING METHODS - AS A TOOL FOR SOCIO-ECONOMIC DEVELOPMENT
}

The article considers the role and importance of information technology in the field of educational services and innovative teaching methods. It has been determined that the use of information and communication technologies in the teaching process in higher education institutions is a necessity that has been accompanied by challenges of the world space, in particular in recent years. It has been determined that the role and mission of the teacher in the educational process is transformed into an organizer, consultant, leader and expert of independent work of students. The importance of modern information and communication technologies in the process of teaching and educational process has been substantiated. The advantages and disadvantages of distance learning, which is caused by the requirements for the adaptation of the world space have been identified. The essence of the concept of "innovation" and systematized modern innovative teaching methods have been studied. The classification of innovations in the field of education and classification of pedagogical technologies has been given. Modern innovative teaching methods have been systematized.

Key words: teaching methods, computer information technologies, Internet.

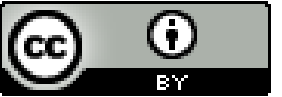

This work is licensed under a Creative Commons Attribution 4.0 International License http://creativecommons.org/licenses/by/4.0/
Statement of the problem and its connection with important scientific and practical tasks. The world without wires today is not a fantasy - but a reality, even a daily reality. Note that the Internet of Things is able to penetrate into all nooks and crannies that are inaccessible and often invisible world, which goes far beyond the action of the organs of sight, hearing and consciousness. It creates new types of networks and systems, completely different routes for information and knowledge. The field of education is not an exception. Even recently, it has become very popular to use distance learning on the basis of the Internet, and the year 2020 showed its necessity. This can be training in a higher education institution, internship abroad, holding international conferences, as well as conducting lectures and practical / laboratory classes, online courses, etc. [1]. Leading information and communication technologies play an important role in the implementation of modern distance learning.

Given that the objective trend in higher education institutions is to reduce the number of classroom (lecture) hours and increase the hours devoted to inde- pendent, individual work of higher education applicants, which is an integral part and important prerequisite for the quality of their training, the remote online learning is in great demand. Thus, the role and mission of the teacher in the educational process is transformed: the function of the teacher as the main source of information gradually loses relevance, he becomes an organizer, consultant who directs the learning process, adjusts it and promotes creative abilities of students, leader and expert of students independent work, as one that corresponds to modern trends in education, focused on supporting the aspirations of the individual to explore, discover, modify the world. All this inspires the search for more efficient and effective learning tools that would perform functions in the educational process: systematizing, informing, controlling, shaping and motivating. Distance learning is more individual learning. First of all, in our opinion, distance learning makes the process of obtaining educational services creative and individual, opens new opportunities for creative self-expression of the applicant [1]. 
The dynamics of educational institution development and socio-economic development depend on the quality of construction of the integrated information automated management system of the university. The problem of informatization is the core around which the whole system of higher education is built. Solving this problem allows to solve the orders of the information society, to train specialists who are able to apply information technology at a modern level in professional activities, in everyday life. It is difficult to imagine a university, the activities of which would be carried out without the development of computer technology, information technology [2]. It is at the time of quarantine that humanity understands what important role technology plays in our lives.

The relevance of this topic is beyond doubt, as many more questions arise for professionals-inventors of information systems and technologies, as well as for people who use and implement all innovative modern Internet things, mainly in the technological and applied aspect. There is also a need to create such methods and forms of teacher-student interaction, which are aimed at encouraging independent learning activities of student youth, as the competence paradigm of education regulates that the real achievement is only the knowledge that a person has acquired independently through their own practical experience.

The analysis of the latest publications on the problem. Analyzing the achievements of different scientists, it can be argued that the study of innovative teaching methods using computer information technology is done by: Rozhkova N.G., Adonin S.V., Kuryacha N.V., Kozyar M.M., Gurevich R.S., Vernigora O.L., Gumenyuk I.P., Zhile P.I., Boyko G.G., Melentyeva K.M., Skochelyas D.I., Tsymbalyuk V.V., Burukova M.V., Gorbatyuk I.O., Yaksmanetskaya R.V., Shkurenko S.V., Chernyshova M.M., Kobysya V.M., Kademiya M.Yu., Kutsak L.V., Kobysya A.P. etc. Without underestimating the contribution of domestic scholars in substantiating this issue, it should be noted that some aspects of the issue are still debatable and need attention for further research.

Forming of the aims of the research. The purpose of this study - the disclosure and systematization of modern existing teaching methods with the use of information and communication technologies, justification of their feasibility in the field of educational process.

Giving an account of the main results and their substantiation. Today, it is difficult to imagine a modern education system without the use of information and communication technologies in the educational process, including the use of computer technology, cloud technology and global information networks. The need to use modern teaching methods at the university using the latest information technology is dictated by the changing role of the teacher in the educational process [3]. In recent years, new priorities for the development of education have been identified in Ukraine, and, accordingly, a complex process of its modernization has begun, taking into account the needs of the modern information and technological society. Ukraine's integration into the Eu- ropean, world space actualizes the task of training a new generation of teachers who are well versed in modern pedagogical technologies [4]. Thus, the importance and necessity of introducing information and communication technologies in teaching and learning methods is substantiated by international experts and scientists. It should be noted that in higher education institutions preference is given to active teaching methods, which are aimed at forming students' independence, variability, creativity, critical thinking. The most powerful source of cognitive activity of higher education students, the development of their creative abilities, interests, skills and other intellectual factors today are new innovative technologies. Innovative technologies in education are primarily information and communication technologies, inextricably linked with the use of computer-based learning [3].

According to Dyadyun SV [5] the use of computers in education has led to the emergence of a new generation of informational educational technologies that have improved the quality of learning, created new means of influence, more effective interaction between teachers and students.

Thus, the informatization of education is a promising way to socio-economic development of society. Learning with the use of information and communication technologies has many advantages, however, we should not abandon the current effective teaching methods. It is worth talking about the synergy of traditional methods and new technologies. Thus, among the advantages of modern information and communication technologies are:

- improving the quality of education and training;

- the ability of man to adapt more quickly to the environment, to socio-economic changes;

- opportunities to apply new methods of teaching and learning;

- large-scale computerization and digitalization provide an opportunity to maximize the creative approach to teaching, to make lessons cognitive, individual [6].

- to improve the content of education, to expand the methods and organizational forms of the educational process;

- provide a highly qualified methodological and scientific level of educational services;

- improve the quality of interdisciplinary links;

- $\quad$ to provide a creative independent approach to learning;

- means of self-improvement.

It should be noted that today high-quality teaching of academic disciplines prevails through the use of tools and opportunities provided by the Internet and information and communication technologies. They create conditions for better presentation of material that is more interesting, the opportunity to quickly test knowledge and increase interest in learning. Thus, according to our social survey among higher education students, to the question: "how is information perceived better in distance learning with or without a presentation?", Everyone answered "usually with a presentation". One of the advantages of 
the presentation in remote mode is the ability not to lose the main ideas of the speaker in case of technical problems (when the sound is lost, etc.).

Therefore, along with many advantages, it should be noted the main disadvantage - incomplete technical support for the necessary computer information technology. It should be noted that a certain share of both students and teachers faced the issue of technical support.

The experience of the countries - economic leaders - convincingly shows that investments in the development of higher education and science at the level of 3$8 \%$ of gross domestic product allow these countries to remain at the level of advanced. And this is understandable, because in the transition from industrial to information society and knowledge economy, the level of development of the country is determined by the level of development of individuals, ie the intellectual potential of the nation [7].

One of the main features of modern society, according to Klyap M., is its development on the basis of innovations. This process is fully implemented in the field of education, as this area determines the progressive economy of each state [8]. The essence of the concept of "innovation" by various sources is given in table 1 .

Table 1

The essence of the concept of "innovation" in the scientific views of various authors *

\begin{tabular}{|c|c|}
\hline Author / source & Definition \\
\hline $\begin{array}{l}\text { Large explanatory dic- } \\
\text { tionary of the modern } \\
\text { Ukrainian language }\end{array}$ & Innovation is a novelty. \\
\hline $\begin{array}{l}\text { Glossary of the Europe- } \\
\text { an Education Founda- } \\
\text { tion }\end{array}$ & $\begin{array}{l}\text { Innovation is a novelty introduced for the first time, but most innovations involve the } \\
\text { transfer of existing approaches to new conditions through their adaptation or gradual } \\
\text { changes to existing systems. }\end{array}$ \\
\hline Roger K. & $\begin{array}{l}\text { Novelty is an idea that is new to a particular person, and it does not matter whether the } \\
\text { idea is objectively new or not. }\end{array}$ \\
\hline Turkot T.I. & $\begin{array}{l}\text { Innovative education is an industry that is constantly updated with knowledge, technolo- } \\
\text { gies, teaching aids, organizational and managerial approaches. }\end{array}$ \\
\hline Dmitry T.O. & $\begin{array}{l}\text { Innovation is a type of novelty that allows you to solve both the problems of today and } \\
\text { prevent similar problems in the future. Innovations in education - is the process of creat- } \\
\text { ing new ideas of pedagogical and managerial technologies for the implementation and } \\
\text { dissemination in educational practice that increase the level of achievement of structural } \\
\text { components of education and as a result there is the transition of the system to a qualita- } \\
\text { tively different state. The source of innovation is a purposeful search for an idea in order } \\
\text { to resolve contradictions, its development is through testing in the form of a pedagogical } \\
\text { experiment or pilot implementation. }\end{array}$ \\
\hline $\begin{array}{l}\text { Abdalova O.I., } \\
\text { Isakova O.Y., } \\
\text { Vasilenko O.V., } \\
\text { Galicia I.O., } \\
\text { Halytsia O.S., } \\
\text { Dokuchaeva V.V., } \\
\text { Fatkhutdinov O.V. }\end{array}$ & $\begin{array}{l}\text { New in the educational process is correlated with such characteristics as useful, progres- } \\
\text { sive, positive, modern, advanced. }\end{array}$ \\
\hline
\end{tabular}

*Systematized on the basis of sources $[8,9,11]$

It should be noted that innovation in the educational process is the result of a creative search for original, non-standard solutions to various pedagogical challenges in the modern world. To ensure future competitive professionals in the labor market there is a need to use new innovative methods and technologies of teaching students in higher education, which is one of the conditions of modern socio-economic development of society.

Thus, innovations in education can be divided into three groups (Fig. 1).

Given the challenges of today, in particular in the field of education, it should be noted that scientists are exploring various innovative teaching methods that allow to use new teaching technologies, and would be motivated (interested would give), effective result (quality education), creativity, fun, etc. (table 2).
Note that Bystrova YV exploring innovative teaching methods in higher education in Ukraine, classifies known pedagogical technologies in educational practice into 6 groups (Fig. 2). So, today there are different teaching methods. Thus, it is possible to organize independent work of applicants for higher education in different ways and for different purposes. Note that among the traditional forms of independent work of students in distance learning is an individual form, which is determined by most teachers, especially in 2020-2021 when studying various disciplines, both theoretical and practical. Among the most effective methods of independent work of students, which contribute to the individualization and intensification of the educational process, it is necessary to highlight the task-search methods and the method of applying the latest information and communication technologies in teaching. 


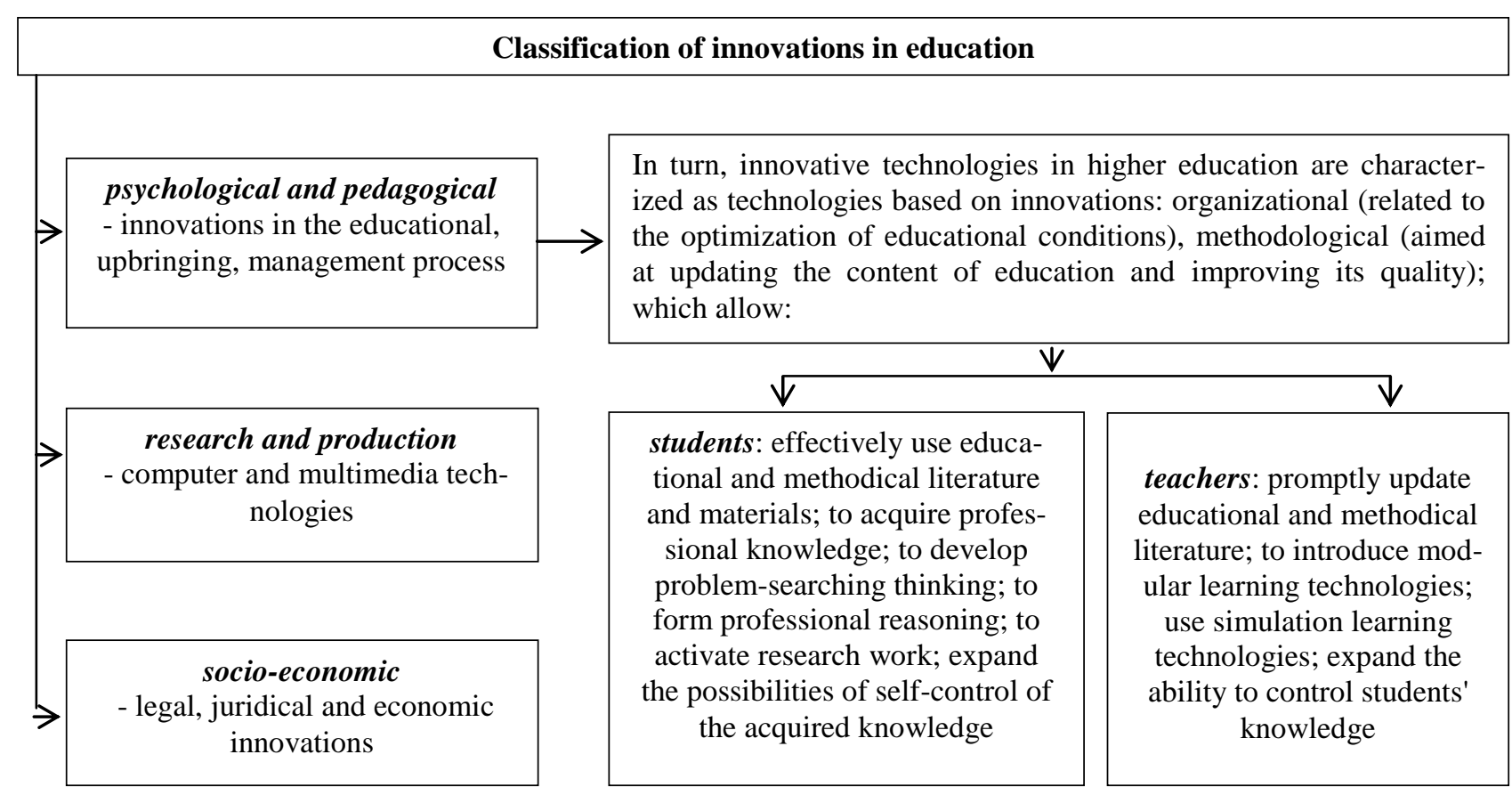

Fig. 1. Classification of innovations in education*

* Systematized on the basis of sources [10]

Table 2

Innovative teaching methods *

\begin{tabular}{|c|c|}
\hline Author & Methods \\
\hline Shestopalyuk O.V. & $\begin{array}{l}\text { Contextual learning, Simulation learning, Problem-based learning Modular learning, Full } \\
\text { acquisition of knowledge, Distance learning }\end{array}$ \\
\hline Morozov V. & Design method, laboratory system (experimental) and integrated (complex method) \\
\hline $\begin{array}{l}\text { Chernilevsky D.V. } \\
\text { Lutsky I.M. }\end{array}$ & Active learning, modular learning, problem-based learning, didactic games \\
\hline Goncharov S.M. & Cooperative collective-group, situational modeling, discussion issues \\
\hline Turkot T.I. & $\begin{array}{l}\text { Group work of students, group trainings, "brainstorming", didactic games, case method, } \\
\text { micro-teaching, method "Talk show", "Circle of ideas", "Aquarium" }\end{array}$ \\
\hline Artikutsa N.V. & $\begin{array}{l}\text { Methods of specific situations, role play, problem-searching, "brainstorming", individual } \\
\text { and group trainings, interview method }\end{array}$ \\
\hline Kochubey A.V. & $\begin{array}{l}\text { Imitation, motivational, cognitive and regulatory methods that are based on dialogic in- } \\
\text { teraction and "make the intellect and soul work" }\end{array}$ \\
\hline Bistrova Yu.V. & $\begin{array}{l}\text { Common teaching methods: types of educational work of students (oral, written; class- } \\
\text { room, independent, extracurricular); general (collective, group, individual, etc.); source } \\
\text { of knowledge and formation of skills and abilities (lecture, document analysis, work with } \\
\text { the legal framework, use of visual aids, Internet resources, etc.); degree of independence } \\
\text { and nature of students' participation in the educational process (active, interactive, pas- } \\
\text { sive); level of stability and novelty (traditional, classical, non-standard, innovative), au- } \\
\text { thorship (original, author's, general, didactic), etc. }\end{array}$ \\
\hline $\begin{array}{l}\text { Abdalova O.I., } \\
\text { Vasilenko O.V., } \\
\text { Halytsia I., } \\
\text { Doronina N.N. }\end{array}$ & $\begin{array}{l}\text { Methods of effective approach: } \\
\text { a) which provide mastery of the subject (verbal, visual, practical, reproductive, problem- } \\
\text { solving, inductive, deductive); } \\
\text { b) which stimulate and motivate educational and scientific activities (educational discus- } \\
\text { sions, problem situations, professionally-oriented business games, creative tasks, search } \\
\text { and research, experiments, competitions, quizzes, etc.); } \\
\text { c) methods of control and self-control in educational activities (survey, test, exam, test, } \\
\text { test tasks, questions for self-control, including through computer educational systems). }\end{array}$ \\
\hline
\end{tabular}

*Systematized on the basis of sources $[8,10,11]$ 


\section{Pedagogical technologies}

structural and logical technologies: step-by-step organization of the learning system, which provides a logical sequence of setting and solving didactic tasks based on the step-by-step selection of their content, forms, methods and tools, taking into account the diagnosis of results;

integration technologies: didactic systems that provide integration of interdisciplinary knowledge and skills, various activities at the level of integrated courses (including electronic);

professional and business game technologies: didactic systems of using various "games", during which the ability to solve problems on the basis of compromise choice (business and role-playing games, simulation exercises, individual training, computer programs, etc.) is formed;

training tools: a system of activities for working out certain algorithms for solving typical practical problems with the help of a computer (psychological training of intellectual development, communication, solving management problems);

information and computer technologies implemented in didactic computer learning systems based on human-machine dialogue with the help of various educational programs (training, control, information, etc.);

dialog-communication technologies: a set of forms and methods of teaching based on dialogic thinking in interacting didactic systems of the subject-subject level.

Fig. 2. Classification of pedagogical technologies *

* Systematized on the basis of sources [11]

For example, when studying the discipline "Management Information Systems and Technologies" higher education students have the opportunity to create a database and fill it with input information, build and perform algorithmic accounting and analytical calculations, evaluate the initial results, generate a report and forecast and make management decisions . And, to provide higher education students with electronic learning resources, management and organization of their independent work, electronic discipline support was downloaded in the Moodle learning management system. These e-learning courses include lectures, laboratory work, presentations to lectures, tests, guidelines for independent and individual work of applicants.

Thus, independent individual work of students in the remote online mode is one of the components of the educational process, and therefore, like all its components, is a system of active organizational and didactic activities aimed at training professionals of relevant educational levels and non-standard creative thinking.

Conclusions and prospects of the further investigations. The study found that the use of computer information technology in the teaching process in higher education is a necessity that has been accompanied by the challenges of the world. And, the active introduction and application of these technologies in the provision of educational services is an effective tool for creating a new education system that meets the requirements of the process of modernization of the traditional education system and information society.

Note that with the introduction of information and communication technologies, teaching methods are changing. Innovative teaching methods should include modern requirements for highly qualified professionals in the global labor market, such as: creativity, ability to work in critical conditions, take responsibility, communication skills, teamwork, competence of their profession, leadership skills, manage their time, understand the importance of deadlines, present and justify their research, etc.

Thus, information and communication technologies cover all areas of human life, but perhaps the most effective impetus and positive development and impact they have on education, in particular, in recent years.

\section{References}

1. Markova, T. D., \& Pchelianska, H. B. (2021). Zabezpechennia yakosti vyshchoi osvity: pidvyshchennia efektyvnosti vykorystannia informatsiinykh tekhnolohii u zdiisnenni osvitnoho protsesu. In zbirnyk materialiv III-i vseukr. nauk.-metod. konf.: Zabezpechennia yakosti vyshchoi osvity: pidvyshchennia efektyvnosti vykorystannia informatsiinykh tekhnolohii u zdiisnenni osvitnoho protsesu (pp. 142-143). Odesa; Odes. nats. akad. kharch. Tekhnolohii. 
2. Kuzminskyi, A. I. Informatsiini tekhnolohii u navchalnomu protsesi ta orhanizatsiino-rozporiadchii diialnosti vyshchoho navchalnoho zakladu. http://enpuir.npu.edu.ua/bitstream/123456789/25399/1/1.pdf

3. Adonin, S. V., \& Kuriacha, N. V. (2021). Suchasni metody vykladannia z vykorystanniam informatsiinykh tekhnolohii. Efektyvna ekonomika, (4). http://www.economy.nayka.com.ua/?op=1\&z=8790. doi: 10.32702/23072105-2021.4.85

4. Rozhkova, N. H. (2014). Vykorystannia informatsiino-komp'iuternykh tekhnolohii yak innovatsiinoho metodu v navchanni inozemnykh mov. Naukovi zapysky, (132), 121-125. doi: 10.1016/j.neucom.2012.06.063

5. Diadiun, S. V. Vykorystannia informatsiinykh tekhnolohii $v$ osviti. https://conf.ztu.edu.ua/wpcontent/uploads/2021/01/131.pdf

6. Alieksieieva, H. M., Kravchenko, N. V., \& Horbatiuk, L. V. (2020). Tekhnolohii yak zasib nabuttia navychok softckils u profesiinii osviti. In zb. nauk. prats materialiv I vseukr. nauk.-prakt. konf.: Dystantsiina osvita $v$ Ukraini: innovatsiini, normatyvno-pravovi, pedahohichni aspekty (pp. 7 - 8), Kyiv; Natsionalnyi aviatsiinyi universytet.

7. Beznosiuk, O. O., \& Ostapchuk, S. V. (2020). Aktualni problemy yakosti osvity v Yevropeiskii i svitovii systemakh pidhotovky fakhivtsiv. In $z b$. nauk. prats materialiv I vseukr. nauk.-prakt. konf.: Dystantsiina osvita $v$ Ukraini: innovatsiini, normatyvno-pravovi, pedahohichni aspekty (pp. 15 - 18), Kyiv; Natsionalnyi aviatsiinyi universytet.

8. Kliap, M. (2015). Innovatsiini metody navchannia u VNZ yak instrument internatsionalizatsii vyshchoi osvity Ukrainy. Vyshcha osvita Ukrainy, (4), 45-53.

9. Berezivska, N. S. (2019). Innovatsiini osoblyvosti v osvitnomu protsesi. In zbirnyk vystupiv uchasnykiv II vseukr.nauk. - prakt. konf. vyshchykh navchalnykh zakladiv Ukrainy: Vykorystannia innovatsiinykh tekhnolohii v osvitnoти prostori. (pp. 6 - 7). Kyiv; Filiia «Bilhorod-Dnistrovskyi ekonomiko-pravovyi koledzh»Vyshchoho navchalnoho zakladu Ukoopspilky «Poltavskyi universytet ekonomiky i torhivli».

10. Shvets, H. O. Suchasni innovatsiini metody vykladannia u vyshchii shkoli. In Chetverta vseukrainska praktychno-piznavalna internet-konferentsiia. https://naukam.triada.in.ua/index.php/konferentsiji/33-chetvertavseukrajinska-praktichno-piznavalna-internet-konferentsiya/42-suchasni-innovatsijni-metodi-vikladannya-u-visshijshkoli

11. Bystrova, Yu. V. (2015). Innovatsiini metody navchannia u vyshchii shkoli Ukrainy. Pravo ta innovatsiine suspilstvo, 1(4), 27-33.

Received 10 May 2021 Approved 24 May 2021

Available in Internet 21.07.2021

Немченко В.В.

доктор економічних наук, професор кафедра обліку та аудиту

E-mail: bossvalera29@gmail.com

ORCID ID: 0000-0002-2984-3357

Пчелянська Г.Б. старший викладач кафредра обліку та аудиту E-mail: gaya_od@ukr.net ORCID ID: 0000-0003-0944-986X

\author{
Маркова Т.Д. \\ кандидат економічних наук, доцент \\ кафедра обліку та аудиту \\ E-mail: markova.tetiana17@gmail.com \\ ORCID ID: 0000-0002-9437-2635 \\ Володіна О.П. \\ асистент \\ кафедра іноземних мов \\ Одеська національна академія харчових технологій \\ вул. Канатна 112, м. Одеса, Україна, 65039E-mail: \\ volodinaolenaonaft@gmail.com \\ ORCID ID: 0000-0003-0552-6733
}

\section{ІНФОРМАЦІЙНІ ТЕХНОЛОГІЇ У ВИКОРИСТАННІ ІННОВАЦІЙНИХ МЕТОДІВ ВИКЛАДАННЯ - ЯК ІНСТРУМЕНТ СОЦІАЛЬНО- ЕКОНОМІЧНОГО РОЗВИТКУ}

У статті розглядається роль та значення інформаційних технологій у сфері надання освітніх послуг та інноваційні методи викладання. На сьогоднішній день якісне викладання навчальних дисциплін переважає за допомогою використання засобів і можливостей, які надають Інтернет та інформаційно-комунікаційні технології. Вони створюють умови для кращої подачі матеріалу, що є більш цікавим, можливість швидко перевірити знання та підвищити інтерес до навчання. В статті визначено, що використання інформаційно-комунікаційних технологій у процесі викладання у закладах вищої освіти $є$ необхідністю, яка супроводжувалась викликами світового простору, зокрема останніми роками. Активне впровадження та застосування цих технологій в просторі надання освітніх послуг є дієвим інструментом створення нової системи освіти, яка відповідає вимогам процесу модернізації традиційної системи освіти та інформаційного суспільства. Авторами визначено, що роль і місія викладача у навчально-виховному процесі трансформується на організатора, консультанта, керівника та експерта самостійної роботи студентів. Обґрунтовано важливість сучасних інформаційно-комунікаційних технологій у процесі викладацько-виховного процесу. Визначенні переваги та недоліки дистанційного навчання, 
яке викликане вимогами до адаптації світового простору. Досліджено сутність поняття «інновації» та систематизовані сучасні інноваційні методи викладання. В статті доведено, що інновація в навчальновиховному процесі - це результат творчого пошуку оригінальних, нестандартних рішень різних педагогічних викликів у сучасних умовах світового простору, який забезпечує майбутніх конкурентоспроможних фахівців на ринку праці. Представлена класифікація інновацій в галузі освіти та класифікація педагогічних технологій. Систематизовано сучасні інноваційні методи навчання, які дозволяють використовувати нові технології викладання, носять мотивований (зацікавлений) характер, мають ефективний результат (якісну освіту), креативність, задоволення. Авторами доведено, що самостійна індивідуальна робота студентів в дистанційному он-лайн режимі $є$ однією з складовою навчально-виховного процесу, а тому, як і всі його компоненти, являє собою систему активних організаційних і дидактичних заходів, спрямованих на підготовку фахівців відповідних освітніх рівнів та нестандартного творчого мислення.

Ключові слова: методи викладання, комп'ютерні інформаційні технології, Інтернет.

\section{Література}

1. Маркова Т.Д., Пчелянська Г.Б. Організація самостійної роботи студентів 3 дисципліни «Інформаційні системи і технології обліку» в дистанційному просторі // Забезпечення якості вищої освіти: підвищення ефективності використання інформаційних технологій у здійсненні освітнього процесу: збірник матеріалів III-ї всеукр. наук.-метод. конф., Одеса, 14-16 квітня 2021p. / Одес. нац. акад. харч. Технологій. Одеса, 2021. С. 142143.

2. Кузьмінський А.І. Інформаційні технології у навчальному процесі та організаційно-розпорядчій діяльності вищого навчального закладу. URL: http://enpuir.npu.edu.ua/bitstream/123456789/25399/1/1.pdf (дата 3вернення 23.04.2021)

3. Адонін С.В., Куряча Н.В. Сучасні методи викладання з використанням інформаційних технологій // Ефективна економіка. 2021. №4. URL: http://www.economy.nayka.com.ua/?op=1\&z=8790. doi: 10.32702/23072105-2021.4.85 (дата звернення 23.04.2021)

4. Рожкова Н.Г. Використання інформаційно-комп'ютерних технологій як інноваційного методу в навчанні іноземних мов // Наукові записки. 2014. Вип. 132. С.121-125. doi: 10.1016/j.neucom.2012.06.063

5. Дядюн С.В. Використання інформаційних технологій в освіті. URL: https://conf.ztu.edu.ua/wpcontent/uploads/2021/01/131.pdf (дата звернення 23.04.2021)

6. Алєксєєва Г.М., Кравченко Н.В., Горбатюк Л.В. Технології як засіб набуття навичок softckils у професійній освіті // Дистанційна освіта в Україні: інноваційні, нормативно-правові, педагогічні аспекти: зб. наук. праць матеріалів I всеукр. наук.-практ. конф., Київ, 16 червня 2020 р., / Національний авіаційний університет. Київ: НАУ, 2020. С.7-8.

7. Безносюк О.О., Остапчук С. В. Актуальні проблеми якості освіти в Свропейській і світовій системах підготовки фахівців // Дистанційна освіта в Україні: інноваційні, нормативно-правові, педагогічні аспекти: зб. наук. праць матеріалів I всеукр. наук.-практ. конф., Київ, 16 червня 2020 р. / Національний авіаційний університет. Київ: НАУ, 2020. С.15-18.

8. Кляп М. Інноваційні методи навчання у ВНЗ як інструмент інтернаціоналізації вищої освіти України // Вища освіта України. 2015. №4. С.45-53.

9. Березівська Н.С. Інноваційні особливості в освітньому процесі // Використання інноваційних технологій в освітньому просторі: збірник виступів учасників II всеукр.наук. - практ. конф. вищих навчальних закладів України. К.: Філія «Білгород-Дністровський економіко-правовий коледж» Вищого навчального закладу Укоопспілки «Полтавський університет економіки і торгівлі», 2019. С.6-7.

10. Швець Г.О. Сучасні інноваційні методи викладання у вищій школі // Четверта всеукраїнська практично-пізнавальна інтернет-конференція. URL: https://naukam.triada.in.ua/index.php/konferentsiji/33-chetvertavseukrajinska-praktichno-piznavalna-internet-konferentsiya/42-suchasni-innovatsijni-metodi-vikladannya-u-visshijshkoli(дата звернення 23.04.2021)

11. Бистрова Ю.В. Інноваційні методи навчання у вищій школі України // Право та інноваційне суспільство : електрон. наук. вид. 2015. № 1 (4).С. 27-33.

Стаття надійшла 10.05.2021 Стаття прийнята до друку 24.05.2021 Доступно в мережі Internet 21.07.2021

Цитування згідно ДСТУ 8302:2015

Nemchenko V., Markova T., Pchelianska G., Volodina O. Information technologies in the use of innovative teaching methods - as a tool for socio-economic development // Food Industry Economics. 2021. Vol.13, Issue 2. P. 105-111. doi: 10.15673/fie.v13i2.2046

Cite as APA style citation Nemchenko, V., Markova, T., Pchelianska, G., \& Volodina, O. (2021). Information technologies in the use of innovative teaching methods - as a tool for socio-economic development. Food Industry Economics, 13(2), 105-111. doi: 10.15673/fie.v13i2.2046 